estetychnoho vykhovannia molodi [The role of the cultural and educational environment of the educational institution in the system of aesthetic education of youth]. Time for art education. [in Ukrainian].

2. Butenko, L.V. (2008). Uchytel literatury: vyiav tvorchosti y krasy. Pidhotovka maibutnikh uchyteliv literatury do interpretatsii khudozhnikh tvoriv. Monohrafiia [Teacher of literature: a manifestation of creativity and beauty]. Preparing the future teachers of literature for the interpretation of works. Kherson.[in Ukrainian].

3. Butenko, N.I. (1996). Estetychnyi dosvid v systemi profesiinoi diialnosti vchytelia [Aesthetic experience in the system of professional activity of a teacher]. Formation of aesthetic experience of works of art. Kherson.[in Ukrainian].

4. Honcharenko, S.U. (2011). Ukrainskyi pedahohichnyi entsyklopedychnyi slovnyk [Ukrainian pedagogical encyclopedic dictionary]. Rivne. [in Ukrainian].

5. Kremen, V.H. (2007). Yakisna osvita i novi vymohy chasu [Quality education and new requirements of time]. Pedagogical and psychological sciences in Ukraine. Theory and history of Pedagogy. [inUkrainian].

Стаття надійшла до редакції 15.08.2020

УДК 37. 013

DOI:

Галина Білавич, доктор педагогічних наук, професор кафедри педагогіки початкової освіти ДВНЗ “Прикарпатський наџіональний університет імені Василя Стефаника"

\title{
ЕНВАЙРОНМЕНТАЛЬНА ОСВІТА ДЛЯ СТАЛОГО РОЗВИТКУ У ВИМІРІ ЮНЕСКО КРІЗЬ ПРИЗМУ ПІДРУЧНИКОТВОРЕННЯ
}

Розглянуто питання енвайронментальної освіти для сталого розвитку у вимірі ЮНЕСКО крізь призму підручникотворення. Зазначено, щуо енвайронментальна освіта розвивається не лише як теорія, а радше як певна практика, спрямована на формування екологічно орієнтованої т. зв. життєвої політики суспільства. Підручники в галузі енвайронментальної освіти пропонують конкретні иляхи природозбереження, гармонійноі взаємодї особи із природою, орієнтують на подальшу гуманну діяльність у довкіллі, а також забезпечують енвайронментальні знання, спрямовані на формування екологічно орієнтованого світогляду; засвоєння системи знань у галузі взаємодії природи і суспільства; виховання екогуманістичного світосприйняття особистості; проєктують розвиток енвайронментального мислення, формування відповідних переконань особистості; формування енвайронментальної поведінки та культури.

Ключові слова: енвайронментальна освіта; підручники; сталий розвиток суспільства; екологічна освіта; ЮНЕСКО.

Jim. 15.

Halyna Bilavych, Doctor of Sciences (Pedagogy), Professor of the Pedagogy of Primary Education Department, State Pedagogical University

"Vasyl Stefanyk Precarpathian National University"

\section{ENVIRONMENTAL EDUCATION FOR SUSTAINABLE DEVELOPMENT FROM THE UNESCO PERSPECTIVE THROUGH THE PRISM OF TEXTBOOK CREATION}

Foreign scholars consider environmental education as an ideology for the human civilization survival, a condition for sustainable development. Sustainable development is a complex and multifaceted concept. It is about such economic development, which is comprehensively balanced and which contains great requirements for environmental protection, environmental security, social justice; it ensures the elimination of exploitation, poverty, discrimination, and so on. The UNESCO Strategy for Education for Sustainable Development emphasizes that as of today, responsibility for the further development of humanity lies on all the citizens, children, youth and adults who are responsible for the environment. And the issues of its protection can be successfully resolved only with the participation of the general public in this process. Therefore, everyone should have access to information, including textbooks, and be able to participate in the environmental decisions. The key functions of textbooks in the field of environmental education are the acquisition of environmental knowledge by children and youth, creating a basis for the formation of a person capable of making appropriate decisions and acting in the interests of environmental protection and sustainable development of the mankind.

The article covers relevant issues of environmental education for sustainable development from the UNESCO perspective through the prism of textbook creation. It is noted that environmental education is developing not only 
as a theory, but rather as a practice aimed at forming an ecologically oriented so-called life policy of society. Textbooks on environmental education offer specific ways of nature conservation, harmonious interaction of people with nature; focus on further humane ecological activities, as well as provide environmental knowledge with a purpose of forming an ecologically oriented worldview; master the system of knowledge in the field of interaction between nature and society; promote the eco-humanistic worldview of the individual; project the development of environmental thinking and formation of appropriate beliefs of the individual as well as formation of environmental behavior and culture.

Keywords: an environmental education; textbooks; sustainable development of society; an ecological education; UNESCO.

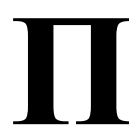

остановка проблеми. На порозі III тисячоліття все людство об'єдналося навколо ідеї сталого розвитку: ii розглядають як ідеологію виживання людської цивілізації. Традиційно під сталим розвитком розуміють систематично керований розвиток, в основі керованості цього складного процесу покладено системний підхід, сучасні інформаційні технології, що дають змогу не тільки оперативно створити різні моделі і варіанти напрямів розвитку, а й з високою точністю зробити прогнози їх результатів та вибрати найбільш оптимальний варіант розвитку суспільства. Сталий розвиток - складне й багатоаспектне поняття. Ідеться про такий економічний розвиток, що $є$ всебічно збалансованим, містить великі вимоги до захисту довкілля, екологічної безпеки, соціальну справедливість, забезпечує ліквідацію експлуатації, бідності та дискримінації тощо. Ще у 80-х рр. ХХ ст. держави-члени ЮНЕСКО актуалізують питання про сталий розвиток, екорозвиток як розвиток без руйнування, необхідність стійкого розвитку екосистем. Так, зокрема, у 1987 р. Міжнародна комісія з довкілля i розвитку (МКНСР) під головуванням експрем'єра Норвегії Г. Х. Брундланд у своїй доповіді “Наше спільне майбутнє” порушила проблему “сталого розвитку” і чітко визначила його зміст: це такий розвиток, що не тільки забезпечує потреби сьогоднішнього покоління людей, а й не створює перешкоди для можливості прийдешніх поколінь задовольнити власні потреби [2].

Ці ідеї, офіційно проголошені в головному документі "Порядок денний на XXI століття” (Agenda 21), ухваленому у 1992 р. на Міжнародній конференції з довкілля і розвитку в бразильському Pio-де-Жанейро (United Nations Conference on Environment and Development (Earth Summit), увиразнили тісний гармонійний взаємозв'язок між довкіллям і соціальноекономічним розвитком, високою якістю довкілля і здоровою економікою для всіх народів світу, задоволенням потреб людей і збереженням сталого розвитку протягом тривалого періоду [2].

Таким чином, екологічна безпека кваліфікується як частина національної і глобальної безпеки людства. Однак після Конференції в Ріо-де-Жанейро, попри всі декларації досягти рівноважного стану між економічним ростом, соціальною спільнотою та довкіллям, цього так і не сталося. Навпаки, ситуація погіршилась і ускладнюється 3 кожним днем, питання збереження біосфери і загалом цивілізації так і залишається відкритим. Актуальність проблеми розглядаємо не тільки в планетарному контексті, а й у державному вимірі. Для України за надзвичайно складних умов сьогодення (наслідки Чорнобильської катастрофи, війна на Сході держави, яка спричинює знищення людського чинника та довкілля, анексія Росією Криму тощо) проблема збереження природного середовища, здоров'язбереження людей стає щораз злободеннішою. Драматизм екологічних реалій України посилюється низьким рівнем екологічної культури людей та їхньої інформованості про екологічну ситуацію у світі, державі, регіоні, де вони мешкають, їх обізнаності 3 можливими шляхами розв'язання різних екологічних проблем, що ускладнює сталий розвиток держави.

На нашу думку, шлях до високої екологічної культури лежить через ефективну екологічну освіту (в англомовних державах енвайронментальна освіта), через екологізацію свідомості громадян. Тому на часі переорієнтація змісту системи освіти у вимірі стійкого розвитку, що передбачає насамперед їі екологізацію розвиток природоохоронного мислення, здобуття екологічних знань, формування природозбережувальної поведінки для того, щоб діти та юнацтво і тепер, і в майбутньому були здатні задовольняти свої потреби без загрози для безпеки природи, не завдаючи їй шкоди, дбали про збереження довкілля, про власне здоров'язбереження, діяли у довкіллі та ухвалювали відповідні рішення не як споживачі, а як свідомі громадяни. Одне із центральних місць у цьому процесі належить створенню якісного навчально-методичного забезпечення, зокрема підручникотворенню.

Мета дослідження - схарактеризувати стан підручникотворення для енвайронментальної освіти для сталого розвитку в провідних 


\section{ЕНВАЙРОНМЕНТАЛЬНА ОСВІТА ДЛЯ СТАЛОГО РОЗВИТКУ}

У ВИМІРІ ЮНЕСКО КРІЗЬ ПРИЗМУ ПІДРУЧНИКОТВОРЕННЯ

державах-членах ЮНЕСКО, показати значення цього процесу для української системи освіти.

Виклад основного матеріалу. Оскільки на початку XXI ст. особливо загострилися екологічні проблеми у зв'язку з погіршенням екологічної ситуації у світі (і в Україні теж), гостро постало питання природозбереження, охорони природи, формування у дітей та юнацтва навичок природозбережувальної поведінки, адже розпочатий у сім’і, дошкіллі, а відтак продовжений у школі процес екологічного виховання природно й логічно має бути організований у закладах вищої освіти. Складність цього процесу зумовлена тим, що юнацтво вступає у самостійне життя в епоху не тільки бурхливого розвитку інновацій, науки, техніки, а й тих викликів, які пов'язані з ризиками, спровокованими негативними наслідками науково-технічної революції, демографічного вибуху тощо. Отже, юним поколінням XXI ст. необхідна нова філософія життя, високий рівень екологічноїкультури, сформованіприродозбережувальні навички. Відтакрозвитокенвайронментальної освіти викликаний не тільки потребою часу, це важлива педагогічна проблема.

Сьогодні Україна, декларуючи курс на європейську інтеграцію, як член ЮНЕСКО приєдналася до міжнародних форумів, які визнають освіту як “базовий елемент трансформації суспільства до сталого розвитку” та “фундамент сталого розвитку” [1]. Ухвалена 2005 році у Вільнюсі (Литва) “Стратегія Європейської економічної комісії ООН освіти для сталого розвитку" наголосила на актуалізації проблеми сталого розвитку та зобов'язала всіх учасників альянсу інтенсифікувати практичні заходи щодо реалізації Декади освіти для сталого розвитку (до 2014 р.). У документі “Стратегія СЕК ООН з освіти в інтересах збалансованого розвитку" [3], зокрема, зазначається, що ключовим елементом їі реалізації мають бути національні (державні) Плани дій з урахуванням фактичного стану справ країни та розроблені й затверджені основоположні документи з ОСР для всіх рівнів освіти. Україна ще у 2001 р. ухвалила Концепцію екологічної освіти, саме початок XXI ст. - успішний і продуктивний період реалізації визначених мети і освітньої політики. Проте через 20 років констатуємо певний регрес щодо випрацювання нормативно-правового поля в ділянці екологізації освіти, створення підручникового фонду для екологічної освіти: на жаль, досі не ухвалений закон "Про екологічну освіту”, на законодавчому рівні не ухвалена ані Концепція освіти для сталого (збалансованого) розвитку, ані Концепція сталого (збалансованого) розвитку, не створено належного навчальнометодичного забезпечення на рівні підручникотворення для забезпечення якісної екологізації шкільної та вищої освіти. На нашу думку, варто ширше використовувати зарубіжний досвід щодо енвайронментальної освіти, актуалізований науковцями ЮНЕСКО [5-15].

Вони, зокрема, наголошують на тому, що підручниковий фонд у цій сфері повинен забезпечити просвіту 3 питань розвитку та збереження довкілля для громадян усіх вікових категорій; включати концепції розвитку та збереження навколишнього середовища 3 аналізом причин, які викликають головні глобальні загрози, при цьому особливу увагу приділити підготовці майбутніх керівників; увиразнити дослідження стану довкілля, включаючи питання придатності води для споживання, санітарії, харчових продуктів й екологічних наслідків використання природних ресурсів тощо [4].

Формування природоохоронних знань у державах-членах ЮНЕСКО здійснюється у контексті реалізації програми дій освіти в інтересах сталого (стійкого) розвитку, яка виступає каталізатором просування принципів стійкого розвитку суспільства. ЮНЕСКО координує зусилля національних урядів щодо включення принципів освіти для стійкого розвитку в освітні програми і національні стандарти якості освіти, у процесі створення підручників, які спрямовані на інтерактивне, орієнтоване на інтереси школяра/студента викладання і навчання, що забезпечує дослідницький, прикладний, а також спрямований на перетворення характер здобуття знань, оновлення освітнього середовища (фізичного, віртуального і онлайнового) задля заохочення учнів до того, щоб діяти, керуючись принципами сталого розвитку $[15,11]$.

У такому ракурсі гармонійно вписуються думки вчених із США, Великої Британії, Свропи, які актуалізують проблему екологічно доцільної поведінки [5; 6; 10], спрямовані на формування екологічно доцільних потреб спілкування людини 3 навколишнім середовищем, збереження його від забруднення та руйнування; людина у своїй діяльності та стосунках 3 природою виявляе стурбованість за можливі наслідки ії перетворення, відчуває відповідальність за рішення, які ухвалює - такий ключовий висновок цих досліджень [13]. Акцентується на правовому аспекті екологічно доцільної поведінки та ціннісно орієнтованих знаннях як важливих компонентах у системі екологічної підготовки дітей та юнацтва.

Загалом зазначимо, що світовий та європейський виміри енвайронментальної освіти 
для сталого розвитку є доволі представницьким. Згадаємо, до прикладу, посібник “The Handbook 01 Environmental Education” [14], який варто сприймати як настільну книгу з енвайронментальної освіти, яка забезпечує читача чіткими рекомендаціями щодо збереження довкілля, розробки, упровадження та оцінки міжпредметних програм енвайронментальної освіти, які діють у Великій Британії. Автори Джой Палмер старший викладач освіти 3 Даремського університету та колишній голова Національної асоціації екологічної освіти (Великобританія) та Філіп Ніл - колишній керівник середньої школи та нинішній генеральний секретар Національної асоціації енвайронментальної освіти (Великобританія) - пропонують аналіз глобальних криз, міжнародної політики щодо енвайронментальної освіти, наголошують, що енвайронментальна освіта - це процес, який упродовж усього життя $\epsilon$ міждисциплінарним і цілісним за своєю природою та застосуванням; розглядають екологічну освіту цілісно, яка включає соціальний, політичний, економічний, технологічний, моральний, естетичний та духовний аспекти, наголошують на ціннісному підході до розв'язання екологічних проблем у закладах освіти. Це покроковий практичний посібник, ефективний ресурс, що допомагає педагогам у створенні ефективної екологічної освітньої програми для їхніх шкіл, дає відповідь на запитання “Що таке енвайронментальна освіта та як іiі реалізувати?” [11].

Не втратила концептуального значення низка документів ЮНЕСКО ("Environmental education and training in Europe.

Background paper for the European Union Conference on EE\&T in Europe" та ін.) [7; 8; 9; 10], які окреслюють європейські та світові вектори енвайронментальної освіти, на які орієнтується сьогодні Україна.

Цікавими у контексті нашої проблеми є дослідження вчених Gratiela Dana Boca and Sinan Saraçlý "Environmental Education and Student's Perception, for Sustainability" [12], які характеризують енвайронментальну освіту та увиразнюють їі роль для сталого розвитку навколишнього середовища. На прикладі Північного центру Університету в Бая-Маре (Румунія), де проведено опитування 358 студентів, вивчено стан енвайронментальної освіти, ii взаємозв'язок зі сталим розвитком, сприйняттям екологічної освіти студентами інженерноелектричних, механічних, економічних спеціальностей, їх ставлення до проблем сталого розвитку, тощо, проаналізовано заходи щодо охорони довкілля, у яких беруть участь студенти.
Зазначмо, що українськими вченими не здійснено аналогічного дослідження.

Висновки та перспективи подальших досліджень. У стратегї ЮНЕСКО з освіти в інтересах сталого розвитку наголошується, що сьогодні відповідальність за подальший розвиток людства покладається на всіх громадян, дітей, юнацтво та дорослих. Саме несуть відповідальність за стан довкілля, і питання його захисту можуть бути успішно розв'язані тільки за участі в цьому процесі широких кіл громадськості. Тому кожен повинен мати доступ до інформації, зокрема й підручників, і можливість брати участь в ухваленні рішень, що стосуються довкілля. Ключовими функціями підручників у ділянці енвайронментальної освіти є засвоєння природоохоронних знань дітьми та юнацтвом, створення підгрунтя для формування особистості, здатної ухвалювати відповідні рішення та діяти в інтересах збереження довкілля і сталого розвитку людства.

Досвід закордоння засвідчує: енвайронментальна освіта сьогодні розвивається не лише як теорія, а радше як певна практика, спрямована на формування екологічно орієнтованої т. зв. життєвої політики суспільства. Підручники в галузі енвайронментальної освіти пропонують конкретні шляхи природозбереження, гармонійної взаємодії особи із природою, орієнтують на подальшу гуманну діяльність у довкіллі, а також забезпечують енвайронментальні знання, спрямовані на формування екологічно орієнтованого світогляду; засвоєння системи знань у галузі взаємодії природи і суспільства; виховання екогуманістичного світосприйняття особистості; розвиток енвайронментального мислення, формування відповідних переконань особистості; засвоєння норм енвайронментальної етики; формування енвайронментальної поведінки та культури. Перспективи подальших студій пов'язуємо із виокремленням базових напрямів у енвайронментальній освіті, аналізі шкільних підручників.

\section{ЛІТЕРАТУРА}

1. Закон України “Про Основні засади (стратегію) державної екологічної політики України на період до 2030 року”. Відомості Верховної Ради (ВВР). 2019. № 16, ст.70. URL: https://zakon.rada.gov.ua/laws/show/269719.

2. Рио-де-Жанейрская декларация по окружающей среде и развитию. Доклад Конференции ООН по окружающей среде и развитию (Рио-де-Жанейро, 3 14 июня 1992 года). ООН, Нью-Йорк, 1993. С. 3-7. URL: http://daccess-dds-ny.un.org/doc/UNDOC/GEN/N92/836/ 57/PDF/N9283657.pdf?OpenElement 


\section{ЕНВАЙРОНМЕНТАЛЬНА ОСВІТА ДЛЯ СТАЛОГО РОЗВИТКУ}

\section{У ВИМІРІ ЮНЕСКО КРІЗЬ ПРИЗМУ ПШРУЧНИКОТВОРЕННЯ}

3. Стратегія ЄЕК ООН з освіти в інтересах збалансованого розвитку. Київ: Аспект-Поліграф, 2006. Бібліотека Всеукраїнської екологічної ліги. Серія “Екологічна освіта і виховання". №3. 40 с.

4. Япринець Т. С. Концепція сталого розвитку в змісті географічної освіти в основній школі. Вісник Черкаського університету. Серія : Педагогічні науки. 2015. №28 (361). C. 47-55.

5. Brennan M. J. (1986). A Curriculum for the Conservation of People and their Environment. The Journal of Environmental Education. Vol. 17. No 4. pp. $1-12$.

6. Cunningham W. P., Cunningham M.A., \& Saigo B. W (2005). Environmental Science: a global concern. Eighth edition. Boston-Toronto: Wm. C. Brown Publishers. $600 \mathrm{p}$.

7. Environmental education and training in Europe. Background paper for the European Union Conference on EE\&T in Europe Brussels 3-4 May. Available at: www.vankempenconsultancy.com $>$ resources

8. Environmental Education in the European Union. (1997). Luxembourg: European Commission. 147 p.

9. Environmental Education in the Schools: Creating a Program that Works! / Ed. Judy A. Braus, David Wood. (1993). Washington: NAAEE. 500 p.

10. Environmental Education: Strategies Toward a More Livable Future / Ed. James A. Swan and William B. Stapp. (1974). NY: John Wiley\&Sons. 349 p.

11. Gordon O. (1995). The handbook of environmental education.Mcgilljournal of education. Vol. 30. No. 2. pp. 214-215.

12. Gratiela D. B. \& Sinan S. (2019). Environmental Education and Student's Perception, for Sustainability, Sustainability, MDPI. Open Access Journal. Vol. 11(6).pp. 1-18, March. DOI: 10.1016/B978-0-08-0970868.91081-X

13. Interdisciplinary Enviromental Approaches (1994). By Utton A. E., Henning D. H. (eds). California: Educational Media Press. p. 49.

14. Palmer J. \& Neal Ph. (1994). The Handbook 01 Environmental Education. London \& New York: Routledge. $267 \mathrm{p}$.

15. Roadmap for Implementing the Global Action Programme on Education for Sustainable Development (2014). UNESCO : Paris, 2014. 38 p.

\section{REFERENCES}

1. Zakon Ukrainy "Pro Osnovni zasady (stratehiiu) derzhavnoi ekolohichnoi polityky Ukrainy na period do 2030 roku" (2019).[Law of Ukraine "On the Basic Principles (Strategy) of State Environmental Policy of Ukraine for the period up to 2030"]. Information of the Verkhovna Rada (VVR). No. 16.p. 70. Available at: https://zakon.rada.gov.ua/ laws/show/2697-19 (accessed 21 Sept. 2019)[in Ukrainian]

2. Ryo-de-Zhaneirskaia deklaratsyia po okruzhaiushchei srede y razvytyiu. Doklad Konferentsyy OON po okruzhaiushchei srede y razvytyiu (Ryo-de-Zhaneiro, 314 yiunia 1992 hoda) (1993). [Rio Declaration on
Environment and Development. Report of the United Nations Conference on Environment and Development (Rio de Janeiro, 3-14 June 1992) / United Nations]. United Nations, New York, pp. 3-7. Available at: http://daccessdds-ny.un.org/doc/UNDOC/GEN/N92/836/57/PDF/ N9283657.pdf? OpenElement (accessed 21 Sept. 2019)[in Russian]

3. Stratehiia YeEK OON $\mathrm{z}$ osvity $\mathrm{v}$ interesakh zbalansovanoho rozvytku (2006). [UNECE Strategy for Education for Sustainable Development]. Kyiv: AspektPolihraf. The library of the All-Ukrainian Ecological League. Series "Environmental education and upbringing".No. 3. 40 p. [in Ukrainian].

4. Yaprynets, T. S. (2015). Kontseptsiia staloho rozvytku v zmisti heohrafichnoi osvity v osnovnii shkoli [The concept of sustainable development in the content of geographical education in primary school]. Bulletin of Cherkasy University. Series: Pedagogical sciences. No. 28 (361). pp. 47-55. [in Ukrainian].

5. Brennan, M. J. (1986). A Curriculum for the Conservation of People and their Environment. The Journal of Environmental Education. Vol. 17. No 4. pp. 1-12. (accessed 26 Sept. 2019) [in English].

6. Cunningham, W. P., Cunningham, M. A., \& Saigo, B. W. (2005). Environmental Science: a global concern. Eighth edition. Boston-Toronto: Wm. C. Brown Publishers. 600 p. [in English].

7. Environmental education and training in Europe. Background paper for the European Union Conference on EE\&T in Europe Brussels 3-4 May. Available at:www.vankempenconsultancy.com , resources (accessed 30 Sept. 2019) [in English].

8. Environmental Education in the European Union. (1997). Luxembourg: European Commission. 147 p. [in English].

9. Environmental Education in the Schools: Creating a Program that Works! Ed. Judy A. Braus, David Wood. (1993). Washington: NAAEE. 500 p. [in English].

10. Environmental Education: Strategies Toward a More Livable Future. Ed.James A. Swan and William B. Stapp. (1974). NY: John Wiley\&Sons. 349 p. [in English].

11. Gordon, O. (1995). The handbook of environmental education. Mcgilljournal of education. Vol. 30. No. 2. pp. 214-215. [in English].

12. Gratiela, D. B. \& Sinan, S. (2019). Environmental Education and Student's Perception, for Sustainability, Sustainability, MDPI. Open Access Journal. Vol. 11(6).pp. 1-18, March. DOI: 10.1016/B978-0-08-0970868.91081-X (accessed 30 Sept. 2019) [in English].

13. Interdisciplinary Enviromental Approaches (1994). By Utton A. E., Henning D. H. (eds). California: Educational Media Press. 49 p. [in English].

14. Palmer, J. \& Neal, Ph. (1994). The Handbook 01 Environmental Education. London \& New York: Routledge. 267 p. [in English].

15. Roadmap for Implementing the Global Action Programme on Education for Sustainable Development (2014). UNESCO : Paris, 2014. 38 p. [in English].

Стаття надійшла до редакції 30.06.2020

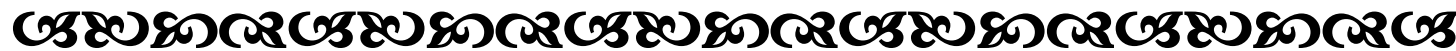

Молодь і ринок №3-4 (182-183), 2020 